\title{
PEMBUATAN KATALOG ONLINE LAYANAN JASA BERBASIS WEB SEBAGAI MEDIA PERIKLANAN PENYEDIA LAYANAN JASA
}

\author{
Abidatul Izzah'), Selvia Ferdiana Kusuma22) \\ \#1,2Teknik Informatika Politeknik Kediri, Kediri \\ 1abidatul.izzah90@ gmail.com, 2mailbox.selvia@gmail.com
}

\begin{abstract}
ABSTRAK
Seiring dengan pertumbuhan perekonomian mikro dan meningkatnya kebutuhan akan penyedia layanan jasa, akhir-akhir ini semakin banyak sekali usaha penyedia layanan jasa yang bermunculan. Namun kebanyakan usaha-usaha tersebut tidak dapat berkembang dengan pesat karena kurangnya promosi yang dilakukan. Kurangnya promosi yang dilakukan oleh penyedia layanan jasa juga membuat konsumen merasa kesulitan untuk mencari informasi tentang penyedia layanan jasa tersebut. Padahal promosi merupakan aspek penting dalam memperkenalkan maupun meningkatkan hasil penjualan sebuah produk maupun jasa. Dalam program pengabdian masyarakat ini, pengusul mengusulkan sebuah cara promosi yaitu berupa penggunaan katalog online untuk mempromosikan usaha penyedia layanan jasa. Penggunaan katalog online ini diharapkan mampu membantu memperkenalkan dan mempromosikan usaha penyedia jasa yang ada di wilayah Kediri. Katalog online ini nantinya akan memberikan informasi tentang nama usaha penyedia jasa, jasa yang ditawarkan, lokasi usaha penyedia jasa tersebut dan nomor telepon penyedia jasa. Adanya katalog online ini diharapkan tidak hanya akan membawa manfaat bagi pemilik usaha penyedia layanan jasa namun juga dapat membawa manfaat bagi konsumennya. Konsumen tidak akan lagi merasa kesulitan mencari layanan jasa yang dibutuhkan karena semua informasi terkait produk layanan jasa yang dibutuhkan sudah disediakan katalog online ini. Program pembuatan Katalog Online ini dilaksanakan dalam 5 tahap: persiapan, analisis kebutuhan, pembuatan katalog, implementasi, dan pembuatan laporan. Diharapkan katalog online ini menjadi media advertensi yang mampu menarik calon pelanggan.
\end{abstract}

Keywords - Katalog Online, Penyedia Jasa, Periklanan

\section{PENDAHULUAN}

\section{A. Analisis Situasi}

Saat ini banyak sekali usaha-usaha kecil menengah yang bermunculan seiring adanya perkembangan perekonomi di sektor mikro. Salah satu usahan kecil menengah yang mulai tumbuh adalah usaha penyedia layanan jasa. Walaupun dengan segala keterbatasan, usahausaha kecil menengah ini berusaha untuk terus bisa berkembang dan menunjukkan eksistensinya.Kenyataannya saat ini banyak sekali usaha kecil menengah di bidang layanan penyedia jasa yang kesulitan untuk mengembangkan usaha mereka. Salah satu alasannya adalah adanya keterbatasan dana untuk melakukan promosi. Padahal promosi merupakan aspek penting dalam memperkenalkan maupun meningkatkan hasil penjualan sebuah produk maupun jasa. Kurang adanya promosi yang dilakukan oleh penyedia layanan jasa membuat konsumen juga merasa kesulitan untuk mencari informasi tentang penyedia layanan jasa tersebut.

Di sisi lain,kemajuan teknologi yang terjadi saat ini tidak hanya berpengaruh di sektor ilmu pengetahuan, namun juga di sektor perekonomian. Hal tersebut terlihat dari banyaknya usaha-usaha yang memanfaatkan jaringan internet untuk mengembangkan usaha mereka. Internet merupakan media informasi yang sangat cepat dan efisien dalam penyebaran informasi, karena tidak terbatas oleh jarak, ruang dan waktu. Melalui website kita dapat memasarkan produk atau jasa yang kita miliki. Namun apabila kita amati, mayoritas website yang ada saat ini hanya memasarkan produk dan bukan layanan penyedia jasa. Sementara diperlukan adanya website yang menyediakan informasi terkait penyedia layanan jasa. Adanya website untuk penyedia layanan jasa, tidak hanya akan membawa manfaat untuk pihak penyedia layanan jasa namun juga untuk pihak konsumen. Dengan memanfaatkan website, pihak penyedia jasa dapat melakukan promosi terkait layanan jasa yang ditawarkan dan pihak konsumen pun dapat mengetahui adanya layanan jasa tersebut melalui website yang telah dibuat oleh pemilik layanan jasa tersebut.

\section{B. Permasalahan Mitra}

Kendala yang dialami pemilik usaha penyedia layanan jasa saat ini adalah cara memasarkan produk layanan jasa tersebut. 
Kurangnya promosi yang dilakukan oleh pengusaha penyedia layanan jasa membuat usaha mereka sulit untuk berkembang. Kurangnya promosi juga mengakibatkan ketidaktahuan konsumen untuk memanfaatkan jasa tersebut.

Adanya keterbatasan dana membuat para pengusaha tersebut harus memikirkan cara untuk melakukan promosi secara efisien. Salah satu solusi yang tepat untuk memasarkan layanan jasa tersebut adalah melalui website. Website dianggap tepat karena jangkauan pemasarannya yang tidak terbatas jarak, ruang dan waktu. Namun apabila dilihat dari segi lain, pembuatan website ini tidak mudah dan tidak murah. Tidak semua pengusaha dapat membuat website mereka sendiri.Dari permasalahan tersebut para pemilik usaha penyedia layanan jasa berharap ada sebuah website khusus yang dapat membantu mereka untuk mempromosikan produk layanan jasa yang mereka miliki.

\section{TARGET LUARAN}

\section{A. Solusi}

Solusi yang diberikan untuk permasalahan ini yaitu pembuatan katalog online berbasis web. Harapannya katalog online berbasis web ini dapat digunakan para pemilik penyedia layanan jasa untuk mempromosikan usaha mereka. Katalog online berbasis web dipilih karena dianggap solusi yang paling efektif dan efisien untuk mengatasi permasalahan yang dihadapi para pemilik usaha layanan penyedia jasa terkait permasalahan promosi. Pemanfaatan katalog online berbasis web dikatakan efektif dan efisien karena penggunaan website sebagai media promosi tidak terbatasi oleh jarak, ruang, dan waktu. Dimana saja dan kapan saja semua orang yang memiliki internet dapat mengetahui informasi tersebut. Promosi ini sangat penting dilakukan agar konsumen mengetahui adanya layanan jasa tersebut. Pemilihan media promosi yang tepat diharapkan dapat membantu para pemilik layanan penyedia jasa untuk mengembangkan usaha yang dimiliki.

\section{B. Target Luaran}

Secara umum output dari program pengabdian masyarakat ini adalah sebuah katalog online berbasis web dengan ekstensi *.com yang memuat informasi tentang penyedia layanan jasa yang dapat menampilkan informasi terkait produk jasa antara lainNama usaha, Bidang usaha, Lokasi usaha, dan Contact Person pemilik usaha. Sehingga secara umum katalog online ini membutuhkan item seperti yang ditunjukkan pada tabel 1 .

TABEL 1 KEBUTUHAN LUARAN

\begin{tabular}{|c|l|c|}
\hline No. & \multicolumn{1}{|c|}{ Jenis Kebutuhan } & Jumlah \\
\hline 1. & $\begin{array}{l}\text { Sewa website domain *.com untuk } 1 \\
\text { tahun }\end{array}$ & 1 \\
\hline 2. & Sewa hosting untuk 1 tahun & 1 \\
\hline 3. & Pembuatan website & 1 \\
\hline
\end{tabular}

Secara khusus output program ini adalah sebuah katalog onlineyang akan menunjukkaninformasi terkait tentang penyedia layanan jasa. Informasi tersebut nantinya akan dikelompokkan berdasarkan kategori-kategori tertentu, diantaranya: jasa servis, jasa perawatan, jasa pertukangan dan jasa laundry. Pada katalog online jasa ini akan terdapat tiga user yaitu Admin sebagai pengelola data, Penyedia sebagai pemilik dan pembuat jasa, dan Pengunjung sebagai pencari jasa.

\section{METODE PELAKSANAAN}

\section{A. Tempat dan Waktu}

Program pengabdian masyarakat ini dilakukan di wilayah Kediri. Waktu pelaksanaan program selama 2 bulan terhitung dari Oktober 2016 s.d. November 2016.

\section{B. Tahap Pelaksanaan}

Program pembuatan website katalog online ini dilaksanakan dalam 5 tahap:

\section{1) Tahap Persiapan}

Pengusul melakukan survey tempat dan proses persiapan program pengabdian. Dalam tahap ini pengusul menganalisis permasalahan dan situasi dari mitra. Di samping itu pengusul juga merancang sebuah solusi berbasis IPTEK yang akan ditawarkan kepada mitra untuk dilaksanakan sebagai program pengabdian IPTEK bagi masyarakat.

\section{2) Tahap Analisis Kebutuhan}

Pengusul bersama-sama mitra akan melakukan analisis kebutuhan dari masingmasing mitra. Kebutuhan mitra dirumuskan untuk kemudian menjadi bahan dari pembuatan katalog online. Secara umum katalog online ini dapat di Gambarkan dalam proses bisnis pada Gambar 1. Proses bisnis adalah suatu kumpulan aktifitas atau pekerjaan terstruktur yang saling terkait untuk menyelesaikan suatu masalah tertentuatau yang menghasilkan produk. Pada proses bisnis yang terlihat pada Gambar 1 pengunjung dapat melihat dan memberikomentar jasa yang diinginkan. Pengunjung dapat mendaftar untuk menjadi penyedia jasa. Penyedia jasa dapat melakukan login untuk mengubah profil dan jasa yang 
ditawarkan. Penyedia dapat melihat hasil pengubahan data yang telah disimpan. Admin dapat melihat dan menghapus data penyedia.Selanjutnya, output dari analisis kebutuhan ini berupa rancangan desain konten website serta Data Flow Diagram (DFD). DFD adalah cara untuk mendokumentasikan pemodelan proses sebelum tahap implementasi dilakukan. Tahap analisis kebutuhan dilakukan sehingga permasalahan mitra akan dirangkum sehingga kemudian dapat diselesaikan melalui pembuatan katalog online.

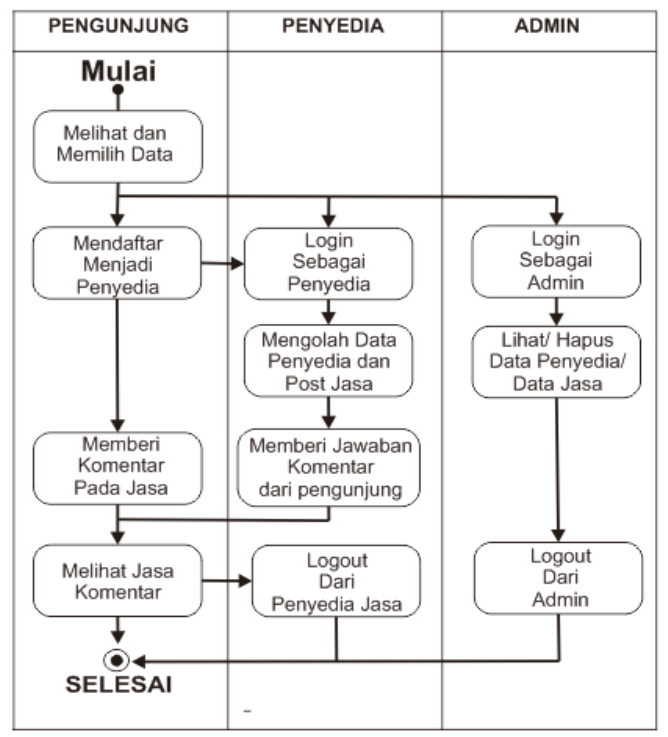

Gambar 1. Proses Bisnis Katalog Online Penyedia Jasa

3) Tahap Pembuatan Website Katalog Online Dari hasil analisis kebutuhan, selanjutnya akan dilakukan pembuatan website katalog online. Selama tahap pembuatan perangkat lunak pengusul dan mitra akan bersama-sama berdiskusi untuk mengevaluasi website katalog online yang akan diimplementasikan. Perancangan dalam pembuatan katalog online dimulai dari perancangan basis data dan desain antarmuka yang disesuaikan dengan DFD hasil sinkronisasi analisis kebutuhan. Perancangan basis data dibuat dengan menyusun Entity Relationship Diagram (ERD) yang berisi komponen-komponen himpunan entitas dan himpunan relasi yang masing-masing dilengkapi dengan atribut-atribut yang merepresentasikan seluruh fakta dari dunia nyata. Pengembangan website dimulai dengan membuat basis data dan tampilan dalam website dengan menggunakan pemrograman PHP dan MySQL. Website yang dibuat berupa kumpulan halaman web yang saling terhubung dan file-file tersebut saling terkait. Katalog yang akan dibangun merupakan sebuah website yang akan memberikan informasi tentang penyedia layanan jasa tersebut.

\section{4) Tahap Implementasi}

Pada tahap ini katalog online telah selesai dibuat. Kemudian katalog online tersebut akan hosting di alamat www.jasakediri.com dan akan disosialisasikan kepada para pemilik layanan jasa di wilayah Kediri. Proses sosialisasi akan dilakukan secara terus menerus hingga dianggap cukup.

5) Tahap Pembuatan Laporan

Pada tahap ini dilakukan proses pembuatan laporan program pengabdian masyarakat. Laporan terdiri dari dokumentasi persiapan, pembuatan, sampai dengan proses sosialisasi.

\section{HASIL DAN PEMBAHASAN}

Pada bab ini dijelaskan tentang fungsi dari halaman, program pada Katalog Online Penyedia Jasa Berbasis WEB. Pembahasan secara detail terdapat pada sub bab berikut :

\section{A. Implementasi Katalog}

\section{1) Struktur Database Katalog}

Database katalog merupakan pusat data yang digunakan oleh aplikasi dimana data tersebut akan ditampilkan sesuai dengan kebutuhan tiap pengguna. Struktur tabel pada aplikasi ditunjukkan pada Gambar 2 sampai dengan Gambar 5. Berikut struktur tabel pada aplikasi:

- Tabel Admin

Tabel Admin difungsikan sebagai penyimpan data admin berupa username dan password agar dapat mengakses halaman admin. Rincian tabel admin ditunjkkan pada Gambar 2.

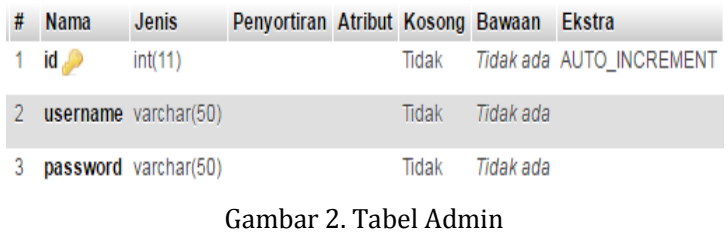

- Tabel Penyedia

Tabel penyedia difungsikan sebagai penyimpan

data penyedia jasa berupa username, password, Gambar, nama, alamatdan telp agar dapat mengakses halaman admin selain itu juga sebagai data untuk ditampilkan di halaman profil penyedia. Rincian tabel penyedia ditunjukkan pada Gambar 3. 


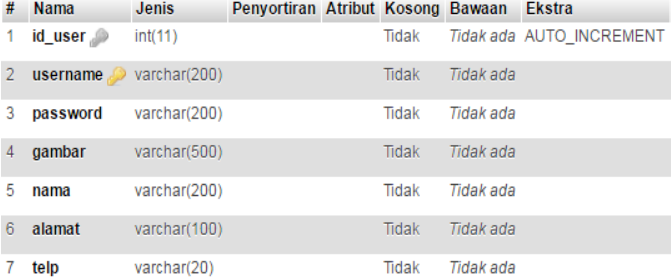

Gambar 3. Tabel Penyedia

- Tabel Jasa

Tabel jasa difungsikan sebagai penyimpan data jasa yang ditawarkan oleh tiap penyedia jasa. Rincian tabel jasa ditunjukkan pada Gambar 4.

\begin{tabular}{|c|c|c|c|c|c|c|}
\hline \# & Nama & Jenis & Penyortiran & Atribut & Kosong & Bawaan Ekstra \\
\hline 1 & id $?$ & int(11) & & & Tidak & Tidak ada AUTO_INCREMENT \\
\hline 2 & $\mathrm{~nm} \_$jasa & $\operatorname{varchar}(50)$ & & & Tidak & Tidak ada \\
\hline 3 & kategori & varchar(50) & & & Tidak & Tidak ada \\
\hline 4 & nm_pemilik & $\operatorname{varchar(50)}$ & & & Tidak & Tidak ada \\
\hline 5 & lokasi & $\operatorname{varchar(50)}$ & & & Tidak & Tidak ada \\
\hline 6 & no_hp & varchar(30) & & & Tidak & Tidak ada \\
\hline 7 & gambar & varchar(50) & & & Tidak & Tidak ada \\
\hline 8 & keterangan & $\operatorname{varchar}(1000)$ & & & Tidak & Tidak ada \\
\hline
\end{tabular}

- Tabel Komentar

Tabel jasa difungsikan sebagai penyimpan data jasa yang ditawarkan oleh tiap penyedia jasa. Rincian tabel komentar ditunjukkan pada Gambar 5.

\begin{tabular}{|c|c|c|c|c|c|c|}
\hline \# & Nama & Jenis & Penyortiran Atribut & Kosong & Bawaan & Ekstra \\
\hline 1 & id_komen ? & int(11) & & Tidak & Tidak ada & AUTO_INCREMENT \\
\hline 2 & id_jasa & $\operatorname{int}(11)$ & & Tidak & Tidak ada & \\
\hline 3 & tanggal & text & & Tidak & Tidak ada & \\
\hline 4 & nama & varchar(50) & & Tidak & Tidak ada & \\
\hline 5 & komen & varchar(500) & & Tidak & Tidak ada & \\
\hline 6 & jawaban & $\operatorname{varchar}(500)$ & & Tidak & Tidak ada & \\
\hline 7 & jasa & $\operatorname{varchar(34)}$ & & Tidak & Tidak ada & \\
\hline
\end{tabular}

\section{2) Interface Katalog}

Interface katalog merupakan tampilan dari website yang telah dibuat. Interface inilah yang antinya akan digunakan user untuk berkomunikasi dengan sistem pada aplikasi. Tampilan interface katalog ditunjukkan gambar 6 sampai dengan gambar 10 . Berikut interface katalog pada aplikasi:

- Halaman Daftar

Form daftar memiliki fungsi untuk menginputkan data penyedia sekaligus sebagai data yang dibutuhkan untuk melakukan login. Tampilan halaman daftar ditunjukkan pada Gambar 6.

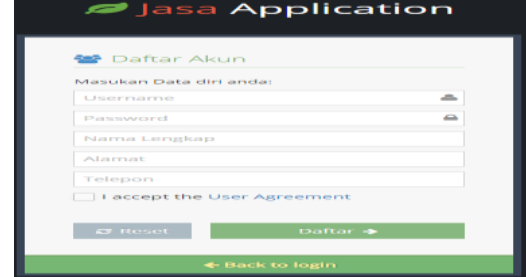

Gambar 6. Halaman Daftar

- Halaman Login

Form Login memiliki fungsi untuk penyedia agar dapat mengakses profil dan jasa yang dimiliki. Tampilan halaman login ditunjukkan pada Gambar 7.

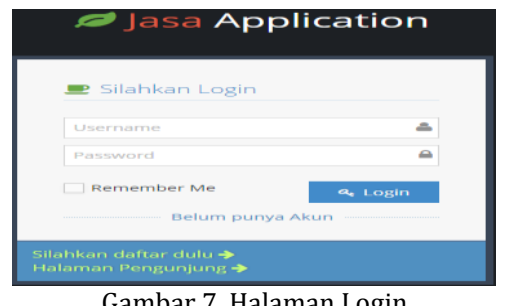

- Halaman Jasa

Halaman Jasa dapat diakses oleh pengunjung, Halaman ini berfungsi untuk menampilkan jasa. pengunjung dapat melakukan post komentar pada halaman ini. Tampilan halaman jasa ditunjukkan Gambar 8.

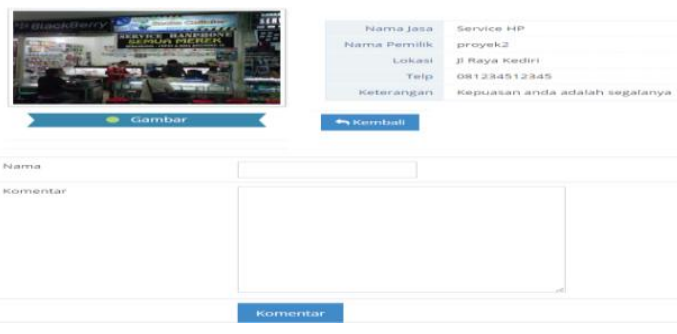

Gambar 8. Halaman Jasa

\section{- Halaman Tambah Jasa}

Halaman dapat diakses oleh penyedia, Halaman ini berfungsi untuk menambah jasa . penedia dapat melakukan penambahan jasa pada halaman ini. Tampilan halaman tambah jasa ditunjukkan pada Gambar 9.

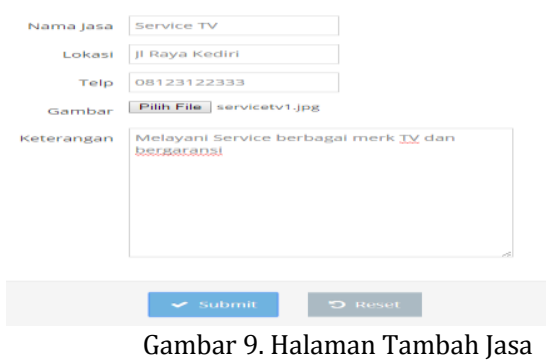




\section{B. Uji Coba Aplikasi}

1) Tampilan Utama Halaman Pengunjung

Tampilan Utama Halaman pengunjung, dapat diakses oleh pengunjung. Uji coba aplikasi dengan contoh "kategori jasa service" halaman ini berfungsi untuk menampilkan data jasa yang tersedia. Pengunjung dapat melihat detail jasa dengan memilih menu detail pada salah satu Gambar pada jasa service. Tampilan utama halaman pengunjung ditunjukkan pada Gambar 10.

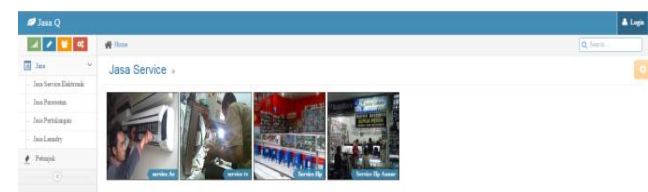

Gambar 10. Tampilan Utama Halaman Pengunjung

\section{2) Pencarian Jasa Oleh Pengunjung}

Pencarian jasa menggunakan fitur search pada aplikasi dapat diakses oleh pengunjung. Uji coba aplikasi dengan contoh memasukkan kata "service hp" pada "kategori jasa service". Tampilan halaman pencarian jasa oleh pengunjung ditunjukkan pada Gambar 11.

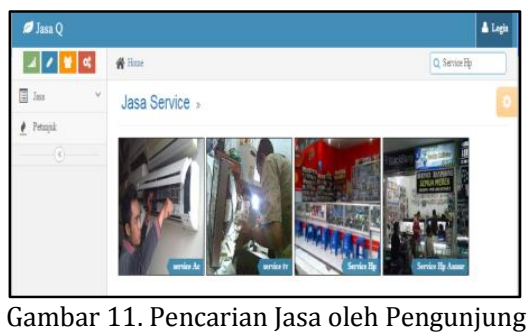

3) Pos Komentar oleh Pengunjung

Pos komentar dijasa tertentu dapat dilakukan oleh pengunjung dengan melihat detail jasa dan memasukan data keformkomentar yang telah disediakan.Uji coba aplikasi dengan contoh memasukkan komentar oleh "Ahmad" pada jasa "Service TV". Pengunjung dapat melihat hasilkomentar yang dimasukkan sesuai dengan jasa yang dipilih. Tampilan halaman pos komentar oleh pengunjung ditunjukkan pada Gambar 12.

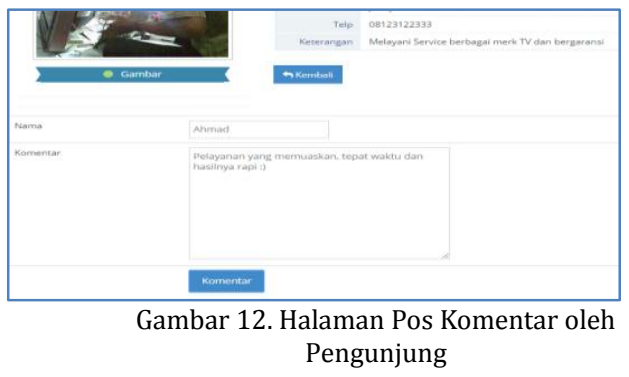

4) Tampilan Awal Penyedia

Tampilan awal penyedia dapat diakses oleh pengunjungyang ingin mendaftar dan penyedia yang akan login berikut tampilan penyedia dan penjelasannya. Tampilanawal penyedia ditunjukkan pada Gambar 13.

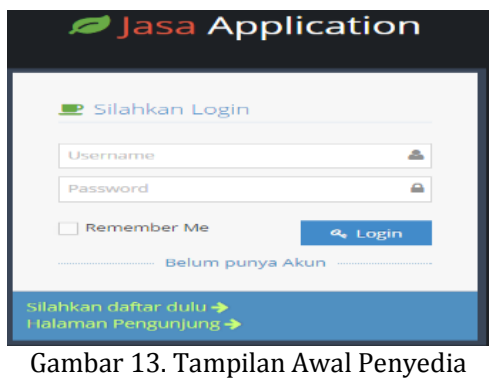

\section{5) Pembuatan Akun Penyedia}

Halaman daftar ini berfugsi agar pengunjung dapat menjadi penyedia jasa. Bagi pengunjung berhasil mendaftar akan diarahkan ke halaman login untuk melakukan proses login. Tampilan pembuatan akun penyedia ditunjukkan pada Gambar 14.

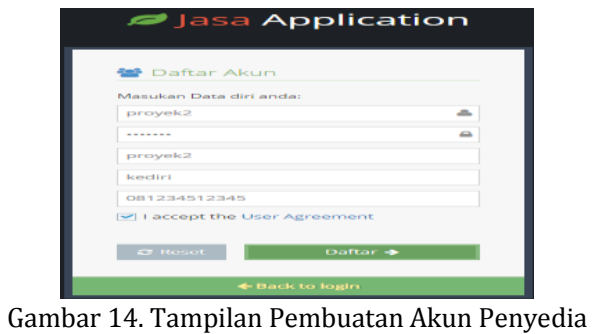

6) Halaman Awal Penyedia

Halaman penyedia ini berfugsi agar penyedia dapat membuat jasa. Jasa yang terdapat pada daftar hanya jasa yang dimiliki oleh penyedia yang membuat. Jika penyedia baru mendaftar maka daftar jasa masih kosong. Tampilan halaman awal penyedia ditunjukkan pada Gambar 15.

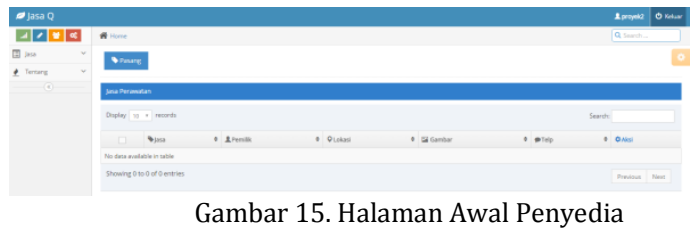

7) Pos Jasa oleh Penyedia

Halaman tambah jasa ini berfugsi untuk memasukkan data jasa kedalam database sesuai dengan nama penyedia jasa. Setelah data dimasukkan secara otomatis halaman akan kembali ke halaman penyedia tampilan. Tampilan pos jasa oleh penyedia ditunjukkan pada Gambar 16. 


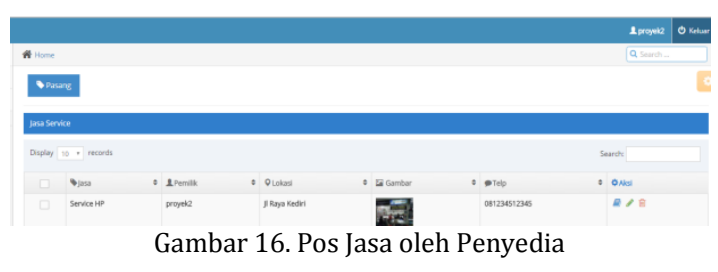

8) Edit Jasa oleh Penyedia

Edit jasa berfungsi bagi penyedia untuk melakukan pengubahan data baik data nama jasa, lokasi,nomor telepon, gambar dan keterangan. Tampilan edit jasa oleh pengguna ditunjukkan pada Gambar 17.

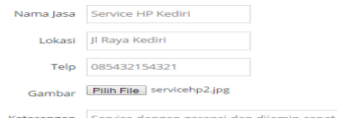

Gambar 17. Tampilan Edit Jasa oleh Pengguna

9) Hapus Jasa oleh Penyedia

Halaman penyedia jasa yang jasanya telah dihapus mengunakan icon hapus pada kolom aksi. Untuk keluar dari penyedia jasa dapat dilakukan dengan cara memilih menu keluar. Untuk mengetahui profil dapat memilih menu tentang > profil kami. Tampilan hapus jasa oleh pengguna ditunjukkan pada Gambar 18.

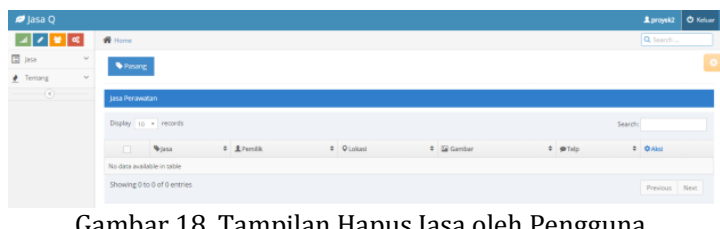

\section{0)Tampilan Admin}

Tampilan awal admin hanya dapat diakses olehberikut tampilan penyedia dan penjelasannya halaman login ini berfugsi agar admin dapat mengakses halama admin dan mengolah data penyedia. Tampilan admin ditunjukkan pada Gambar 19.

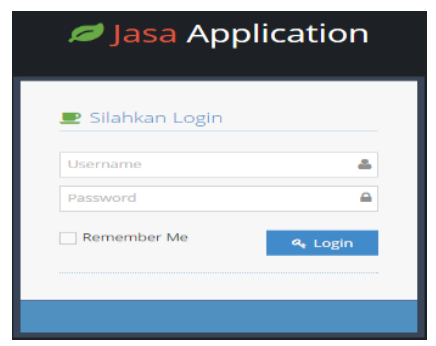

Gambar 19. Tampilan Admin

\section{1)Login oleh Admin}

Uji coba ini bertujuan agar mengetahui bahwa hanya akun admin yang dapat mengakses halama admin dan mengolah data penyedia. Tampilan login oleh admin ditunjukkan pada Gambar 20.

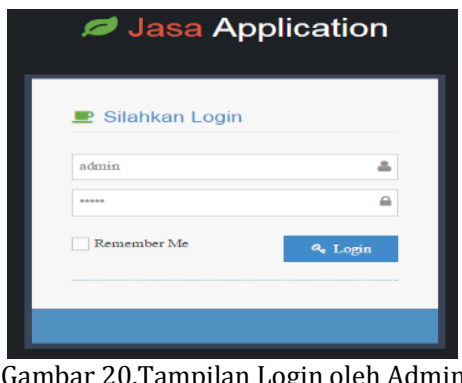

12)Halaman Awal Admin

Setelah admin berhasil login secara langsung diarahkan ke halaman menu awal dimana admin dapat memilih menu sesuai dengan kebutuhan. Tampilan halaman awal admin ditunjukkan pada Gambar 21.

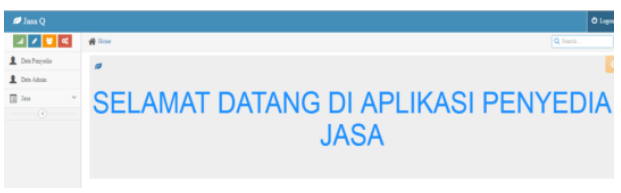

Gambar 21. Tampilan Awal Admin

\section{3)Hasil Uji Halaman Daftar Penyedia}

Halaman daftar penyedia, dimana semua penyedia jasa terlihat dalam satu daftar. Admin dapat menghapus akun penyedia jasa dengan menekan ikon pada kolom aksi sesuai dengan nama akunyang ingin dihapus. Tampilan halaman daftar penyedia oleh admin ditunjukkan pada Gambar 22.

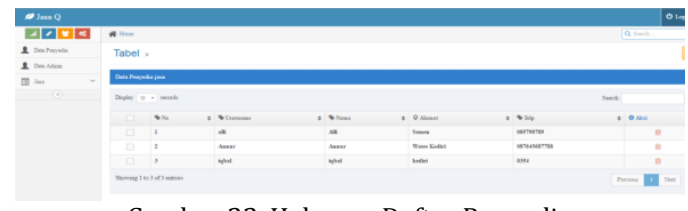

Gambar 22. Halaman Daftar Penyedia

14)Hasil Uji Halaman Daftar Penyedia

Setelah penyedia jasa dihapus maka profil dan jasa yang dipasang didalam katalog akan ikut terhapus. Uji joba dilakukan dengan menghapus salah satu dari tiga penyedia yang ada. Tampilan hasil uji halaman daftar penyedia ditunjukkan pada Gambar 23.

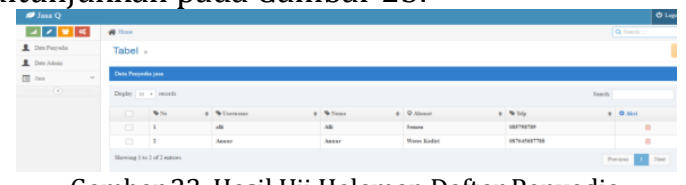

Gambar 23. Hasil Uji Halaman Daftar Penyedia 
15) Halaman Daftar Jasa

Halaman daftar jasa, dimana semua jasa dapat dilihat sesuai dengan kategori. Admin dapat melihat iklan dan komentar pada jasa yang dipilih dengan menekan icon detail dikolom aksi. Tampilan halaman daftar jasa ditunjukkan pada Gambar 24.

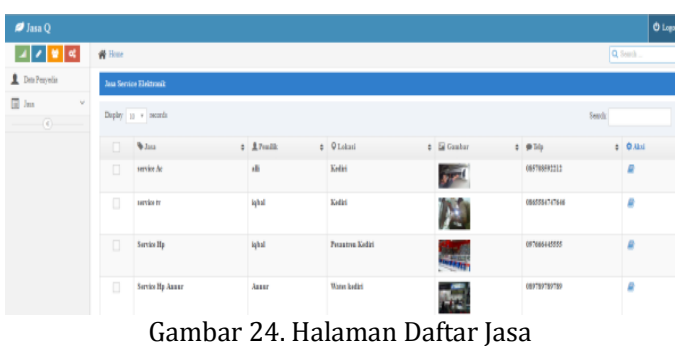

16)Halaman Detil Jasa

Halaman detail jasa, dimana semua jasa dapat dilihat sesuai dengan kategori. Admin dapat melihat iklan dan komentar pada jasa yang dipilih dengan menekan icon detail dikolom aksi. Tampilan halaman detil jasa ditunjukkan pada Gambar 25.

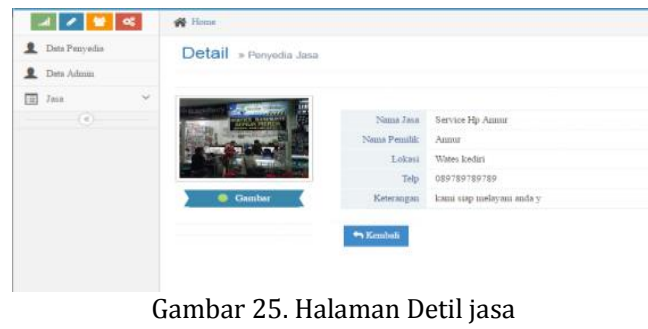

17) Halaman Daftar Admin

Halaman Tambah admin, dimana super admin dapat melihat daftar dan menambah akun yang dapat mengakses halaman admin. Tampilan halaman daftar admin ditunjukkan pada Gambar 26.

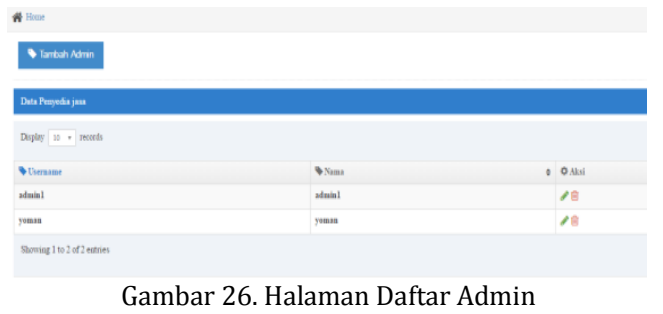

18)Uji Halaman Tambah Akun Admin

Halaman Tambah admin, dimana super admin dapat melihat daftar dan menambah akun yang dapat mengakses halaman admin. Uji coba dilakukan dengan menambah akun admin baru memiliki username. Tampilan halaman tambah akun admin ditunjukkan pada Gambar 27.

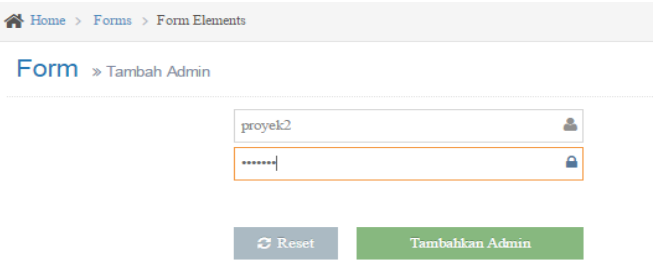

Gambar 27. Uji Halaman Tambah Akun Admin

\section{9) Halaman Ubah Admin}

Halaman ubah akun admin, dimana super admin dapat melihat daftar dan mengubah akun yang dapat mengakses halaman admin. Tampilan halaman ubah akun admin ditunjukkan pada Gambar 28.

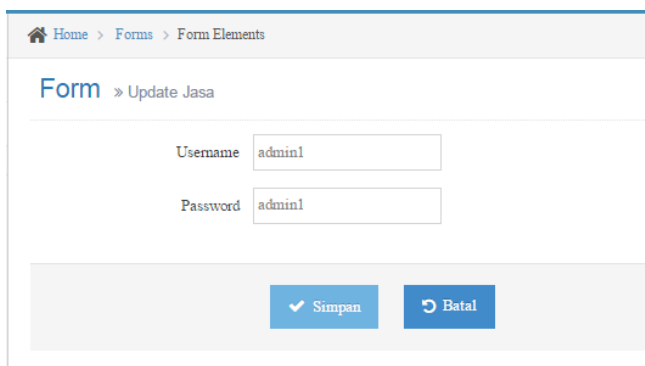

Gambar 28. Halaman Ubah Akun Admin

\section{0)Hapus akun Admin}

Fungsi ini digunakan untuk menghapus akun sehingga admin tersebut tidak dapat lagi mengakses halaman admin. Tampilan halaman hapus akun admin ditunjukkan pada Gambar 29.

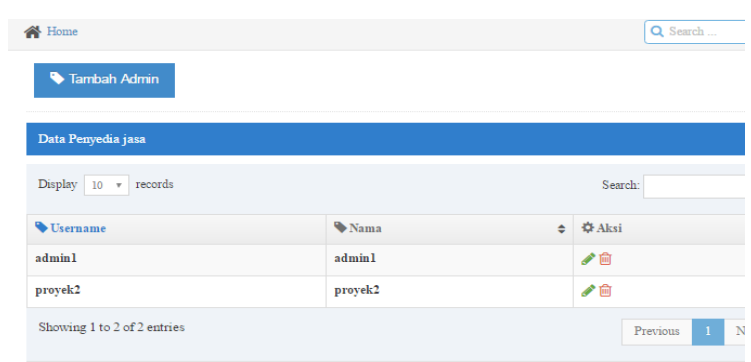

Gambar 29. Halaman Hapus Akun Admin

\section{Sosialisasi kepada Pemilik Usaha Layanan} Jasa

Langkah terakhir dari program ini adalah sosialisasi katalog online yang telah dibangun kepada pemilik usaha layanan jasa. Sosialisasi dilakukan kepada beberapa pelaku usaha yang beraada di area Kediri, Jawa Timur.

Langkah pertama sosialisasi adalah pembuatan akun untuk para pelaku usaha. Pembuatan akun dilakukan oleh penyedia yang bersangkutan. Hal ini bersifat privasi Karena dalam membuat akun diperlukan username dan password untuk kemudian digunakan 
untuk masuk ke sistem katalog. Pembuatan akun diawali dengan mengakses alamat web katalog online di www.jasakediri.com. Antarmuka awal dari web ini dapat dilihat pada Gambar 30.

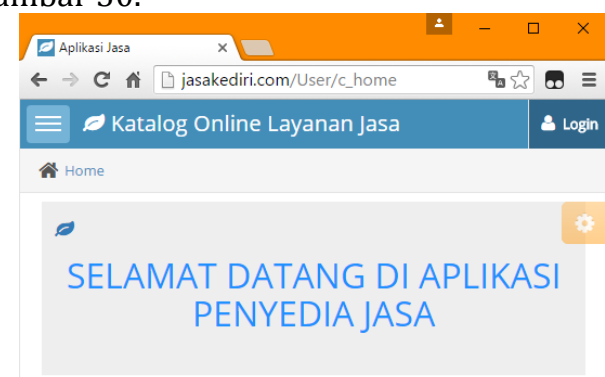

Gambar 30. Tampilan Awal Katalog Online

Langkah selanjutnya adalah memasukkan informasi tentang usaha jasa yang sedang dilakukan. Dalam pemberian informasi ini pelaku usaha dapat memberikan gambaran singkat terkait usaha mereka. Gambar 31(a) menunjukkan contoh informasi usaha Service TV di daerah kab. Kediri dan Gambar 31(b) menunjukkan contoh informasi usaha Laundry di Kab. Kediri.

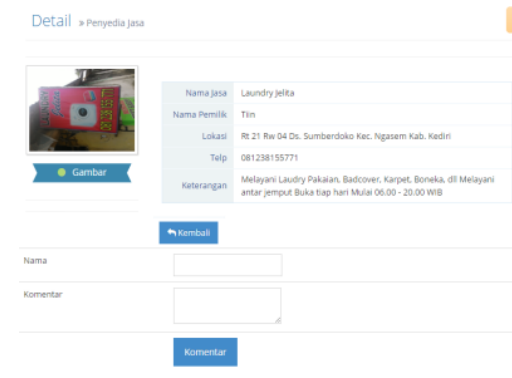

(b)

Gambar 31. Informasi Jasa di Katalog Online (a) Informasi Penyedia Layanan Jasa kategori Service(a) Informasi Penyedia Layanan Jasa kategori Laundry

Sosialisasi kepada pemilik usaha layanan jasa dilakukan untuk memberitahukan adanya website penyedia layanan jasa Kediri kepada pemilik usaha. Gambar-gambar berikut merupakan dokumentasi proses sosialisasi kepada pemilik uasaha layanan jasa.

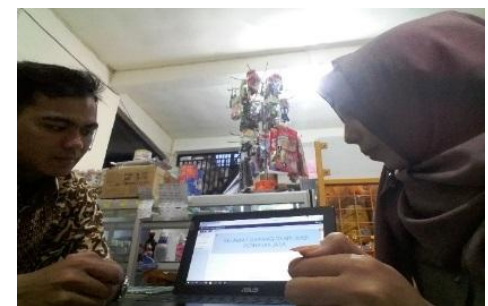

Gambar 32. Sosialisasi Website Kepada Pemilik Usaha Layanan Jasa

\section{KESIMPULAN}

Berdasarkan implementasi yang telah dilakukan dapat ditarik kesimpulan bahwa katalog online penyedia jasa area Kediri berbasis web mempunyai informasi yang jelas dan akurat mengenai pelayanan jasa yang ada di area Kediri. Aplikasi ini berfungsi sesuai dengan tujuan yang hendak dicapai yakni terciptanya sistem penyediaan jasa secara online yang dapat memudahkan pengunjung untuk mengetahui berbagai jasa yang ada di sekitar kota Kediri. Penulis berharap website penyedia layanan jasa ini bisa dipergunakan dengan baik. Selain agar antara penyedia dan pengunjung dapat saling membantu untuk mencapai tujuan yang diinginkan, katalog ini bersifat gratis tanpa dipungut biaya.

\section{DAFTAR PUSTAKA}

[1] Hasibuan Melayu, 2001. Manajemen Sumberdaya Manusia, PT Toko Gunung Agung : Jakarta.

[2] Muyadi, 2001. Akutansi Biaya Edisi 5, Aditya Media : Jakarta

[3] Prasetio Adhi, 2015. Pintar Web Master Untuk Pemula, Mediakita : Jakarta Selatan.

[4] Peranginangin, 2006. Aplikasi Web dengan PHP dan MySQL,Andi Offset : Yogyakarta.

[5] Sidik Betha, 2011. Javascript, Informatika Bandung : Bandung. 